\title{
A Possible Method for the Socio-Economic Efficiency Estimation of Smart City Projects, Paying Particular Regard to their Digital Technology Content
}

\author{
Maxim Vasilyevich Chernyaev ${ }^{1 *}$, Timofey Mikhailovich Mazurchuk¹, \\ Tatyana Fedorovna Kreidenko ${ }^{2,3}$ \\ 1 National Economy Department, Faculty of Economics, Peoples' Friendship University of Russia, 117198 Moscow, \\ 6 Miklukho-Maklaya str., Russian Federation \\ 2 Department of Regional Economics and Geography, Faculty of Economics, Peoples' Friendship University of Russia, \\ 117198 Moscow, 6 Miklukho-Maklaya str., Russian Federation \\ ${ }^{3}$ Department "Economics of Organization", Financial University under the Government of the Russian Federation, \\ 125167 Moscow, 49 Leningradsky Ave., Russian Federation \\ * Corresponding author, e-mail: max.vas.cher@yandex.ru
}

Received: 14 November 2020, Accepted: 13 May 2021, Published online: 28 January 2022

\begin{abstract}
The digitalisation of the urban environment is one of the key areas for the development of modern urban studies. The projects within the framework of the "Smart City" concept are being implemented not only with a view to digital transformation and automation of urban processes, but also with the aim of achieving a comprehensive increase in the efficiency of the urban infrastructure, Hence, the purpose of this research paper is to propose the most effective estimation methods for the socio-economic changes taking place in Russia. The research consists in an analysis of urban infrastructure digitalisation projects, focusing on the most socially and economically profitable ones, both in terms of performance and functionality, in particular. The main set of research tools consists of searching and selecting information, analysing and processing statistical data, as well as generating a multi-purpose method for the project socio-economic efficiency assessment. Based on this methodology, it is possible to offer optimal solutions and forecast efficiency at the project development stage.

The article is concerned with the digital technology projects implemented by the Ministry of Construction of the Russian Federation as a part of the "Smart City" development programs. The authors have concluded that adopting the multi-purpose methods for identifying the socio-economic impact of the "Smart City" digitalisation projects would accelerate the new technology implementation and efficient management of the entire "Smart City" system.
\end{abstract}

\section{Keywords}

smart city, urban infrastructure digitalisation, environmental management, assessment of the digital technology implementation, urban infrastructure

\section{Introduction}

The digitalisation of the urban environment is one of the most important priorities of large urban agglomerations in most countries across the globe. The digital systems contribute not only to the acceleration of data exchange and the increase of its accuracy, but also to the development of services and solutions for the urban improvement as a part of the "Smart city" concept.

Digitalisation is a complex concept that includes all aspects of the digital technologies' implementation that allow a person to perform one's tasks more efficiently, speed up various processes and exclude unnecessary components from the system. For the authors of the work, this concept also encompasses innovations aimed not only at individuals, but also at the life of society in an urban agglomeration, which makes it possible to increase labour efficiency and the safety of citizens, as well as to minimise damage to the environment.

In 2012, the Ministry of Construction, Housing and Utilities of Russia developed a digital environment development program titled "Smart City". During the period of the "Digital Cities" development strategy, 365 projects 
were implemented at the federal and regional levels, along with more than 2000 projects at the municipal level. However, at present, no unified system for quality and efficiency control and monitoring of the projects being implemented has been established; each metropolitan region keeps a record of indicators based mainly on the regional programs. This system does not afford the possibility of fully transferring the experience of cities that have already implemented urban environment digitalisation projects to the emerging projects in cities that are just taking the first "steps" towards the development of smart and accessible urban space (Russias Smart City) (see in Table 1).

Since 2012, 365 federal projects for a total amount of $1,082.8$ billion roubles have been implemented, most of which are aimed at ensuring the information accessibility and communication system development. A significant part of the projects is used for improving the energy efficiency of urban mains, as this is one of the most demanded socio-economic areas in modern Russia. The remaining indicators are formed mainly due to the need to modernise the obsolete infrastructure.

Despite the above figures on the scope of urban project implementation as a part of the digital concept "Smart City", there is no single method for assessing the socio-economic efficiency of the measures and decisions taken. Therefore, in this research paper, the most effective methods will be selected and analysed to determine the socio-economic efficiency of the projects on digital urbanism and environmental management "Smart city" (Kreydenko and Chernyaev, 2019).

To carry out the research, it is important not only to find and select the necessary material, but also to structure all the components, since information from statistical databases both at the federal and regional levels is not only incomplete, but also contains the same indicators and meanings with different names. In addition, in the current study, despite the selected range from 2012 to 2020, the names of the indicators have been selected according to the new list of the Ministry of Construction of Russia, approved in 2017.

\section{Materials and methods}

The main research methods include: search and selection of key indicators and indices, analysis of statistical databases, comparison and correlation of indicators to identify data dependencies, detection of factors that influence the selection of efficient digitalisation projects within the Smart City programmes, with due regard to the introduced projects of the Ministry of Construction of Russia. The search and selection of indicators specifying the project
Table 1 Projects of the Ministry of Construction of the Russian Federation on the urban environment digitalization as a part of the "Smart City" concept in 2012-2020

\begin{tabular}{lcc}
\hline $\begin{array}{l}\text { Name of the "Smart City" } \\
\text { program section }\end{array}$ & $\begin{array}{c}\text { Number of } \\
\text { projects }\end{array}$ & $\begin{array}{c}\text { Total expenditures, } \\
\text { mln USD }\end{array}$ \\
\hline Transport & 41 & 484.1 \\
Heat supply & 11 & 160.5 \\
Ecology & 10 & 229.3 \\
Information city and systems & 180 & $2,763.1$ \\
Energy efficiency & 41 & 5,251 \\
Water supply & 14 & $1,564.3$ \\
Safety & 47 & 369.4 \\
Waste & 5 & 445.8 \\
Power supply & 10 & $1,095.5$ \\
Construction & 6 & $1,430.6$ \\
Total & 365 & $13,793.6$ \\
\hline
\end{tabular}

Source: Compiled by the authors

efficiency was arranged and systematised into 4 main sub-indices (smart housing and utility infrastructure, innovations for the urban environment, intellectual public and environmental safety, infrastructure and services).

To study the issues of methodology for the selection of the most socially and economically efficient urban projects, we have analysed both the federal statistical databases (reports of the Ministry of Construction of the Russian Federation, the Federal State Statistical Service of the Russian Federation, etc.), regional statistical databases, including the municipal level, as well as the regulatory framework. One of the key analytical problems is the discrepancy between the indicators used in the federal and regional reporting within the development of "smart city" projects, and, accordingly, the impossibility of assessing projects without using the most multi-purpose indicators and indices.

In Russia, according to the Ministry of Construction of the Russian Federation, this concept is based on five key principles:

- focus on human development;

- producibility of urban infrastructure;

- urban resource management quality improvement;

- comfortable and safe environment;

- emphasis on economic efficiency, including the service component of the urban environment (Vasilenko, 2019).

It should be noted that most of the subjects began to master digitalisation prior to introduction of the "smart city" state program that led to a severe differentiation of indicators used in reporting. Therefore, all indicators were combined into 4 groups, and formed for the project assessment: 
- smart housing and utility infrastructure;

- Innovations for the urban environment;

- Intelligent public and environmental safety;

- Infrastructure and services.

\section{Results}

The systematisation and establishment of the multi-purpose "flexible" methods based on the socio-economic efficiency improvement factors of digitalisation projects in the Russian cities have made it possible to identify general trends and patterns in the development of a "smart" urban environment and demonstrated the importance of its implementation in terms of economic efficiency.

During the methodology preparation process, it is possible to make a more efficient selection of design materials at the design stages, giving preference to the better solutions, both in the large metropolitan areas and in small cities, where digitalisation is just beginning to be introduced into the urban environment.

\section{Discussion}

Every year the city digitalisation evolves from an abstract concept into the real activities of various states. According to the IDC estimates, the worldwide expenditures on digital transformation will exceed $\$ 1.5$ trillion in 2020. However, there is still no comprehensive approach to assessing the digitalisation progress both in the world practice and in a single country. Nevertheless, the research and measurement of the digitalisation progress is one of the key stages for the development both for the certain country and for individual participants in the digital economy. The lack of research in this area motivated the analysis of the formation features of multi-purpose factors for assessing the efficiency of all "smart city" development projects (Lighting Technologies ESCO).

The projects within the "Smart City" concept are aimed at increasing the city competitiveness, establishment of an effective urban management system, provision of safe and comfortable living conditions for the citizens.

The "Smart City" objective is not only digital transformation and process automation, but also a comprehensive increase in the urban infrastructure efficiency. The key projects in this area are being implemented by the Ministry of Construction, Housing and Utilities of the Russian Federation (Ministry of Construction, Housing and Utilities of the Russian Federation 2019a).

During the research of the urban environment digitalisation projects in Russia, the authors identified over 280 indicators that were used in reporting on the results of "smart city" projects. Having studied the statistical database, four large groups of indicators were specified that were subsequently used for statistical analysis. These groups of indicators most capaciously reflect the environmental situation in the city, well-being and social development of the citizens, system producibility and innovations for the economic development of the infrastructure. Since for most cities the statistical data on factors was not given in full, five cities were used for the study, with a complete statistical overview since 2012. Until 2012, the assessment was made according to other indicators without a single standard (Russias Smart City (Table 2).

Moscow is the leader in terms of completed projects. Since 2012, 278 projects in the field of urban environment digitalisation have been implemented in Moscow. More than $65 \%$ project were aimed at solving environmental issues and sustainable management of urban resources for pollution abatement. The remaining cities in Table 2 have also implemented a significant number of projects within the Smart City concept (226 out of 365).

The leadership of Kazan and Saint-Petersburg, as shown by the analysis of sub-indices based on the open data sources, was positively influenced by the high investment activity of these regions. For example, the Innopolis

Table 2 Top-5 Russian cities by the number of projects implemented as a part of the "Smart City" concept in 2012-2020

\begin{tabular}{|c|c|c|c|c|c|c|}
\hline City & Moscow & Kazan & Saint-Petersburg & Kaluga & Yekaterinburg & Total \\
\hline Number of the "Smart City" concept projects & 64 & 58 & 43 & 32 & 29 & 226 \\
\hline $\begin{array}{l}\text { Investment volumes for the "Smart City" } \\
\text { concept projects, mln USD }\end{array}$ & 602.6 & 301.9 & 421.7 & 240.8 & 273.9 & 1840.9 \\
\hline $\begin{array}{l}\text { Number of the regional urban environment } \\
\text { digitalization projects }\end{array}$ & 214 & 84 & 174 & 112 & 72 & 656 \\
\hline $\begin{array}{l}\text { Investment volumes for the regional urban } \\
\text { environment digitalization projects, mln USD }\end{array}$ & $16,205.5$ & $1,039.5$ & 1,400 & 583.4 & 355.4 & 2338.8 \\
\hline Total number of projects & 278 & 142 & 217 & 144 & 101 & 882 \\
\hline Total in mln USD & 16808.1 & 1341.4 & 1821.7 & 824.2 & 629.3 & 21424.7 \\
\hline
\end{tabular}

Source: Compiled by the authors 
project has a significant positive impact on Kazan in the field of digitalisation development. It can also be noted that a feature of the Republic of Tatarstan's approach to digitalisation is its focus on the applied use of these processes. According to the open data sources, Kazan considers the issue of digital technology introduction with a specific end goal in mind, namely, an increase in labour productivity in the republic's industry and the production diversification at the enterprises (Ageev and Chernyaev, 2010).

To improve the accuracy of sub-indices, they were assessed through the factors that determine the degree of the urban development. The next indicators were selected for each sub-index group that were most often used in the assessment:

\subsection{Smart housing and utility infrastructure}

- Renovation of the housing stock with due regard to the use of modern building standards and producibility of the service delivery processes;

- Fulfilment of the housing construction and/or renovation contracts;

- Introduction of the heat and electric power automatic control systems, as well as data transmission systems for the general network;

- Availability of infrastructure units regulated by the construction standards;

- Introduction of adaptive systems, including the use of cloud services and artificial intelligence (Government of the Russian Federation, 2016)

\subsection{Innovations for the urban environment}

- Standardisation of regulatory and technical documentation;

- Stepwise rejection of the obsolete technologies in the urban environment design;

- Introduction of accessible routes and means of transportation, including the service development of services using the location-based equipment:

- Digitalisation of public space;

- Involvement of residents in the regulation of municipal administrative units (Kreidenko and Sharkova, 2020).

\subsection{Intelligent public and environmental safety}

- Urban space division due to the environmental safety and its improvement in residential areas;

- Economic protectability of citizens (mortgage lending, provision of beneficial services, professional advancement and retraining of employees);

- Social environment adaptive to the needs of residents, including those with impaired mobility;
- Open state tendering structure and the reporting accessibility for citizens;

Use of green public transport and waste minimisation in the residential areas (mos.ru Official website of the Mayor of Moscow).

\subsection{Infrastructure and services}

- Provision of services for the citizen participation in solving the district development issues on the territory with implementation of projects to create a comfortable urban environment;

- Establishment and promotion of technological and digital platforms for business and potential consumers;

- Time reduction for submitting and reviewing documentation from the legal entities and individuals to the government authorities, as well as update of the regulatory and technical documentation for the applicable processing base;

- Creation and evaluation of pilot projects for the experimental technology implementation that contribute to the solution of key issues of the urban development;

- Consideration and use of third-party experience to increase the economic returns from the introduced projects (Government of the Russian Federation, 2020).

This approach provides an optimal assessment of the project implementation quality, since all the above factors are used during annual reporting by the municipal administrations. According to the factors provided, having considered the number of introduced projects and the scale of financing, it is possible to identify influence asserted by the implemented digital projects on the urban development and contribution to the "Smart City" concept promotion (Ministry of Construction, Housing and Utilities of the Russian Federation, 2019b)

The quality of life indicator is determined by the predicted change in a number of aspects, such as life expectancy, economic well-being, pathology and disease odds, as well as tourism appeal. This indicator was developed by the Ministry of Construction of Russia in 2017 to compile a rating and ranking of the Russian cities. This indicator can be used for research ( Federal State Statistics Service, 2019) (Table 3).

According to the data given in Table 3, it can be concluded that the quality of life indicator can be improved with the introduction of digital projects. The greatest increase is shown in the "infrastructure and services" sub-index. The other sub-indices are: Smart housing and utility infrastructure, Innovations for urban environment, and Intelligent 
Table 3 Verification of dependence of the quality of life improvement on the digital project introduction in the analysed cities

\begin{tabular}{lcccc}
\hline Indicator & $\begin{array}{c}\text { Design } \\
\text { factor }\end{array}$ & $\begin{array}{c}\text { Standard } \\
\text { error }\end{array}$ & $\begin{array}{c}\text { Mean value } \\
\text { significance } \\
\text { factor }\end{array}$ & $\begin{array}{c}\text { Error } \\
\text { probability }\end{array}$ \\
\hline $\begin{array}{l}\text { Smart housing } \\
\text { and utility } \\
\text { infrastructure }\end{array}$ & 1.11002 & 0.12301 & 12.24365 & 0.09282 \\
$\begin{array}{l}\text { Innovations for } \\
\text { urban environment }\end{array}$ & 1.24798 & 0.10176 & 11.75412 & 0.22553 \\
$\begin{array}{l}\text { Intelligent public } \\
\text { and environmental } \\
\text { safety }\end{array}$ & 1.28323 & 0.03532 & 14.87536 & 0.39292 \\
$\begin{array}{l}\text { Infrastructure and } \\
\text { services }\end{array}$ & 1.53581 & 0.14867 & 18.73923 & 0.17348 \\
$\begin{array}{l}\text { Intercept } \\
\begin{array}{l}\text { Determination } \\
\text { factor }\end{array}\end{array}$ & 0.09783 & 0.06932 & 3.13261 & 0.00013 \\
\hline
\end{tabular}

Source: Compiled by the authors

public and environmental safety also have a positive effect on the quality of life. However, improvement of the financial well-being and the urban environment accessibility in "infrastructure and services" sub-index take the highest priority in the urban infrastructure digitalization.

The growth in the column "Design factor" (Table 3) is also confirmed by the average indicators for all constituent entities of the Russian Federation. The arithmetic mean value for all cities of the Russian Federation selected for analysis in Table 3 reached a value of 1.29 that corresponds to the positive quality of life trends during the digitalisation project implementation. According to the statements of the Ministry of Construction of Russia, the facts relating to the urban digitalisation based on the different methodology also correspond to the public strategic developmental approaches and global trends (National Housing and Urban Environment Project).

It is important to note that these projects are performed not only at the expense of public funding, but also by attraction of the third-party investments, therefore, it is also necessary to consider the possible economic returns (Table 4).

The econometric matrix in Table 4 demonstrates the possible economic returns from 1 unit of invested finances into each of the 4 sub-indices for 3 types of cities: the cities under study, the cities with a population of 12-100 thousand people and the cities with a population from 100 thousand people to 1 million people. The econometric model with a number above 1 million people showed a significance error of over $72 \%$ that indicates the need for an individual approach. The significance error in the remaining groups did not exceed $10 \%$. The largest return on investments in the sub-indices can be brought by the
Table 4 Matrix of correlation indices for the digital project introduction as a part of the "Smart City" projects in 3 types of cities, with a difference in economic efficiency

\begin{tabular}{|c|c|c|c|}
\hline $\begin{array}{l}\text { Types of } \\
\text { cities } \\
\text { Indicators } \\
\text { for determining } \\
\text { economic output }\end{array}$ & $\begin{array}{l}\text { In the } \\
\text { cities } \\
\text { under } \\
\text { study }\end{array}$ & $\begin{array}{c}\text { In the cities with } \\
\text { a population of } \\
12-100 \text { thousand } \\
\text { people }\end{array}$ & $\begin{array}{l}\text { In the cities with } \\
\text { a population of } \\
100 \text { thousand } \\
\text { people }-1 \mathrm{mln} \\
\text { people }\end{array}$ \\
\hline $\begin{array}{l}\text { Digital project } \\
\text { management as a part } \\
\text { of "Smart City" concept }\end{array}$ & 1.00000 & 0.87423 & 0.86234 \\
\hline $\begin{array}{l}\text { Smart housing and } \\
\text { utility infrastructure }\end{array}$ & 1.11002 & 0.73828 & 0.63729 \\
\hline $\begin{array}{l}\text { Innovations for urban } \\
\text { environment }\end{array}$ & 1.44798 & 0.92831 & 1.08321 \\
\hline $\begin{array}{l}\text { Intelligent public and } \\
\text { environmental safety }\end{array}$ & 0.78323 & 1.02929 & 0.92821 \\
\hline $\begin{array}{l}\text { Infrastructure and } \\
\text { services }\end{array}$ & 1.33581 & 1.28192 & 1.74920 \\
\hline Determination factor & 0.03532 & $\begin{array}{c}\text { Standard } \\
\text { deviation of } \\
\text { variable }\end{array}$ & 2.53292 \\
\hline
\end{tabular}

Source: Compiled by the authors

projects in the field of infrastructure and services, and also for the medium and large cities with a population of 100 thousand people to 1 million people. In the small towns, a positive economic return is observed in the category of "Intelligent public and environmental safety". The highest negative indicators are given in the "Smart housing and utility infrastructure" section that is due to the long payback period of the urban facility construction and the cost of overhaul repairs. This section is also unprofitable due to the inclusion of urban cultural and administrative facilities that cannot bring economic benefits due to belonging to the public structures. The remaining indicators are more cross-functional. Therefore, it is possible to conclude that, based on all sub-indices, the selected projects can bring socio-economic benefits to both the city and the entire state (Government of the Russian Federation, 2020).

The study has demonstrated that the sub-indices can be used for possible analysis of the environmental development project efficiency, while using not only the formalized quantitative indicators that have already been analysed earlier in a number of studies, but also metadata that must be considered when assessing the digital economy progress to consider the differences in the strategies, approaches and priorities of various regions and economic participants. It is also possible to change the indicators to determine the project 
efficiency more accurately. The method is especially relevant in the context of adoption and implementation of the Digital Economy of the Russian Federation program that, like the Smart City, sets the task of developing unified strategic approaches to digitalisation at the federal level. The volume and quality of data in the open sources make it possible not only to obtain information about the digitalisation processes taking place in the country, but also to evaluate these processes (Nezhnikova et al., 2020).

The digitalisation assessment performed on the basis of this approach can be used by the authorities both to control the ongoing programme fulfilment processes, and by the third-party observers from the statistical groups, as well as by the Russian and foreign investors in order to make strategic, investment and production decisions, especially in the field of high-tech initiatives and product ranges related to the digital economy. In particular, it is worth mentioning the civic position and accessibility of this information for the urban residents in order to assess operation of the public authorities and enterprises in the regions, as well as for the media - to notify the general public about the ongoing digitalisation processes (Edler and Fagerberg, 2017).

\section{Conclusion}

In the modern world, the digitalisation of the urban environment not only affects the social development and health of the citizens, but is also one of the key indicators for the urban economic development. According to the research study, the return on investment in the "smart city" projects in most cases brings additional income and stimulates the active growth of digitalisation. The self-development and self-sustainment mechanisms of the "smart city" projects are gradually reducing the share of forced external investments and loans, ensuring the independence of municipal and regional budgets.

In view of the foregoing, several significant conclusions can be drawn:

1. According to the calculations of the efficiency of implementing «Smart City» indicators presented in Table 3, it is possible to propose standardisation of the models for introducing innovations in Russia. However, it is important to take the return on investment into account. In Table 4, the development of infrastructure and services can be the most optimal in both small and large cities in terms of payback; therefore, solutions in this area should be introduced at the early stages of project development. Renovation and modernisation of housing and communal services are the least profitable factors, but no less important; therefore, the search for subsidies from the federal budget and within the framework of existing programmes could stimulate regional administrations to modernise housing and communal services.

2. When creating the first projects, one of the serious obstacles to the digitalisation development may be underfunding both at the federal and regional levels. This is especially true for those constituent entities of the Russian Federation where the problem of the budget shortfall has not been resolved, and the local businesses cannot independently implement large investment projects. Interregional or foreign investors cannot co-finance the programmes, most often due to the lack of the necessary amount of information relating to the urban environment potential, which makes it impossible to launch the projects. These factors can be minimised by providing greater reporting standardisation based on the key indicators that will serve as the basis for the potential project evaluation.

3. Digital inequality and the absence of an urban infrastructure necessary to accept projects as a part of the "smart city" concept or similar projects may persist in places. The lack of high-quality Internet access and the unavailability of regional specialists make it impossible even to prepare draft projects, which indicates the low involvement of small towns in Russia into the federal projects with large investment grants. There are still a lot of problems, especially in the lagging regions of the Russian Federation, relating to the introduction of modern cellular communication standards. In 2020 , only $42 \%$ of cellular communications stations support the modern fourth-generation mobile Internet standard. The implementation of the fifth-generation standard will begin no earlier than in 2023.

4. Absence and/or poor elaboration of training courses and disciplines relating to new professional occupations both in the general school curricula and in the higher educational institutions are both significant obstacles, together with the lack of centralisation and general application of regional digital projects, experience and best practice exchange. None of the projects of the Ministry of Construction of Russia according to the "Smart City" concept is considered as interregional, i.e. there is no cooperation to establish the larger-scale design solutions covering the opportunities of neighbouring urban agglomerations. 
5. There is a general lack of motivation among the industrial state-owned enterprises, except in the agricultural sphere, due to the fact that access to the world markets has been limited by the sanction restrictions imposed since 2014, while domestic orders do not require digital modernisation, since the current producibility level is sufficient for its fulfilment. It is especially worth noting that there is a "stratification" of regional statistical resources by the constituent entities of the Russian Federation in terms of the complete presentation of digitalisation data. The most lagging regions cover the digitalisation results less fully, possibly since digitalisation may seem less relevant to them in comparison with other activities taking place.

Using the example of the cities under study, the authors believe that it is possible to establish the most multi-purpose

\section{References}

Ageev, P. G., Chernyaev M. V. (2010) "New Technologies as the Basis for Optimization of State and Subsurface user Relations", Oil \& Capital. 6(169), Article number: 32.

Edler, J., Fagerberg, J. (2017) "Innovation policy: what, why, and how", Oxford Review of Economic Policy, 33(1), pp. 2-23. https://doi.org/10.1093/oxrep/grx001

Federal State Statistics Service "Технологическое развитие отраслей экономики" (Technological development of economic sectors) [online] Available at: https://rosstat.gov.ru/folder/11189 [Accessed: 23 October 2020] (in Russian)

Government of the Russian Federation (2018) "Указ Президента РФ от 7 мая 2018 г. N 204 "О национальных целях и стратегических задачах развития Российской Федерации на период до 2024 года" " (Presidential Decree No. 204 of May 7, 2018 "On national goals and strategic objectives of the development of the Russian Federation for the period up to 2024"), [pdf] Government of the Russian Federation, Moscow, Russia. Available at: https://policy.asiapacificenergy.org/ node/3854 [Accessed: 23 October 2020] (in Russian)

Government of the Russian Federation (2020) "Федеральный закон от 24.04.2020 № 123-Ф3: О проведении эксперимента по установлению специального регулирования в целях создания необходимых условий для разработки и внедрения технологий искусственного интеллекта в субъекте Российской Федерации - городе федерального значения Москве и внесении изменений в статьи 6 и 10 Федерального закона "О персональных данных" " (Federal Law No.123-FZ dated April 24, 2020 "On experiment to establish special regulation relating to the necessary conditions for the artificial intelligence technology development and implementation in the constituent entity of the Russian Federation (the federal city of Moscow) and amendments to Articles 6 and 10 of the Federal Law "On Personal Data"), [pdf] Government of the Russian Federation, Moscow, Russia. Available at: http://publication.pravo.gov.ru/Document/View/0001202004240030 [Accessed: 22 October 2020] (in Russian) methods for identifying the socio-economic benefits of the "smart city" digitalisation projects that, in turn, would help accelerate the new technology implementation in the cities and efficient management of the entire "smart city" system in Russia.

\section{Acknowledgment}

This paper has been supported by the RUDN University Strategic Academic Leadership Program (Recipient M.V. Chernyaev, detected and systematized factors that influence the digitalization projects' selection, analyzed the methodology for selecting the efficient urban projects; Recipient T. M. Mazurchuk, compared and correlated model indicators and identified data dependencies; Recipient T. F. Kreidenko, identified general trends and patterns in the development of "smart" cities in Russia).

Government of the Russian Federation (2016) "Федеральный закон от 03.07.2016 № 368-Ф3 "О внесении изменений в Градостроительный кодекс Российской Федерации" " (Federal Law No.368-FZ dated July 03, 2016 "On amendment of the Town Planning Code of the Russian Federation"), [pdf] Government of the Russian Federation, Moscow, Russia. Available at: http:/ publication.pravo.gov.ru/Document/View/0001201607040153 [Accessed: 22 October 2020] (in Russian)

Kreidenko, T. F., Sharkova, A.V. (2020) "Platform-based business models for the public transport development", In: International Scientific and Practical Conference: Digital Finance 2020, Moscow, Russia, pp. 14-18.

Kreydenko T.F., Chernyaev M.V. (2019) "Подходы к оценке уровня внедрений технологий 'Умный город'" (Approaches to Assessing the Level of 'Smart city'), Innovation \& Investment, 1, pp. 223-228. (in Russian)

Lighting Technologies ESCO (LLC) "Creation and implementation of the "Smart City" system" [online] Available at: https://ltesco.com/ service/smart-city?yclid $=5634437389175777148$ [Accessed: 20 October 2020]

Ministry of Construction, Housing and Utilities of the Russian Federation (2019а) "Приказ Минстроя России от 24 апреля 2019 г. № 235/пр 'Об утверждении методических рекомендаций по включению мероприятий по цифровизации городского хозяйства в государственные программы субъектов Российской Федерации и муниципальные программы формирования современной городской среды в рамках реализации федерального проекта 'Формирование комфортной городской среды'" (Order No.235/pr of the Ministry of Construction of Russia On the approval of instructional guidance for the inclusion of the urban economy digitalization measures in the state programs of the constituent entities of the Russian Federation and municipal programs for the formation of the modern urban environment as a part of the federal project "Establishment of a comfortable urban environment"), [pdf] Ministry of the Russian Federation, Moscow, Russia, Available at: https://minstroyrf.gov. ru/docs/18508/ [Accessed: 22 October 2020] (in Russian) 
Ministry of Construction, Housing and Utilities of the Russian Federation (2019b) "Приказ Минстроя России от 4 февраля 2019 г. № 80/ пр: Об организации исполнения ведомственного проекта Министерства строительства и жилищно-коммунального хозяйства Российской Федерации по цифровизации городского хозяйства 'Умный город' и о порядке организации в Министерстве строительства и жилищно-коммунального хозяйства Российской Федерации отбора муниципальных образований в целях реализации пилотных проектов в рамках ведомственного проекта Министерства строительства и жилищно-коммунального хозяйства Российской Федерации по цифровизации городского хозяйства 'Умный город'" (Order of the Ministry of Construction of Russia No.80/pr dated February 4, 2019: On the implementation of the departmental project of the Ministry of Construction, Housing and Utilities of the Russian Federation on the urban economy digitalization "Smart City" and on the procedure of the Ministry of Construction, Housing and Utilities of the Russian Federation for selection of municipal entities to implement the pilot projects as a part of the departmental project of the Ministry of Construction, Housing and Utilities of the Russian Federation on urban economy digitalization "Smart City"), [pdf] Ministry of the Russian Federation, Moscow, Russia, Available at: https://minstroyrf.gov.ru/docs/17961/ [Accessed: 22 October 2020] (in Russian)

mos.ru Official website of the Mayor of Moscow "Москва 2030 - комфортная, развивающая, культурная и безопасная городская среда для каждого человека" (Moscow 2030 - A comfortable, developing, cultural and safe urban environment for everyone) [online] Available at: https://2030.mos.ru/ [Accessed: 22 October 2020]
National Housing and Urban Environment Project "Контрольная деятельность" (Control activities) [online] Available at: https:// minstroyrf.gov.ru/trades/kontrolnaya-deyatelnost/ [Accessed: 22 October 2020] (in Russian)

Nezhnikova, E., Chernyaev, M., Solovieva Y., Korenevskaya, A., (2020) "Modernization Concept of the Electric Power Industry as the Basis for Ensuring the Economic Growth of the Russian Federation", In: Popovic, Z., Manakov, A., Breskich, V. (eds.) VIII International Scientific Siberian Transport Forum: TansSiberia 2019, Springer, Cham, Switzerland, pp. 832-843. https://doi.org/10.1007/978-3-030-37919-3_83

Russias Smart City "Register of the draft solutions banks of the Russian smart cities in 2012-2020", [online] Available at: https://russiasmartcity.ru/projects [Accessed: 22 October 2020] (in Russian)

Vasilenko, I. А. (2019) "Формирование социально-политической концепции "умный город" в политической науке: модели и технологии (2019)" (Formation of the socio-political concept of "smart city" in political science: models and technologies in 2019), [online] Available at: https://polit.msu.ru/science/ research/19-011-31440/ [Accessed: 23 October 2020] (in Russian) 